\title{
Effect of Land Configuration, Irrigation and INM on Growth, Yield and Water Use Efficiency of Indian Bean (var. GNIB-21)
}

\author{
H.B. Sodavadiya*, V.R. Naik and S.D. Chaudhari \\ Department of Agronomy, N. M. College of Agriculture, Navsari Agricultural University, \\ Navsari-396 450, (Gujarat) India \\ *Corresponding author
}

\begin{tabular}{|c|c|}
\hline & A B S T R A C T \\
\hline & \multirow{6}{*}{ 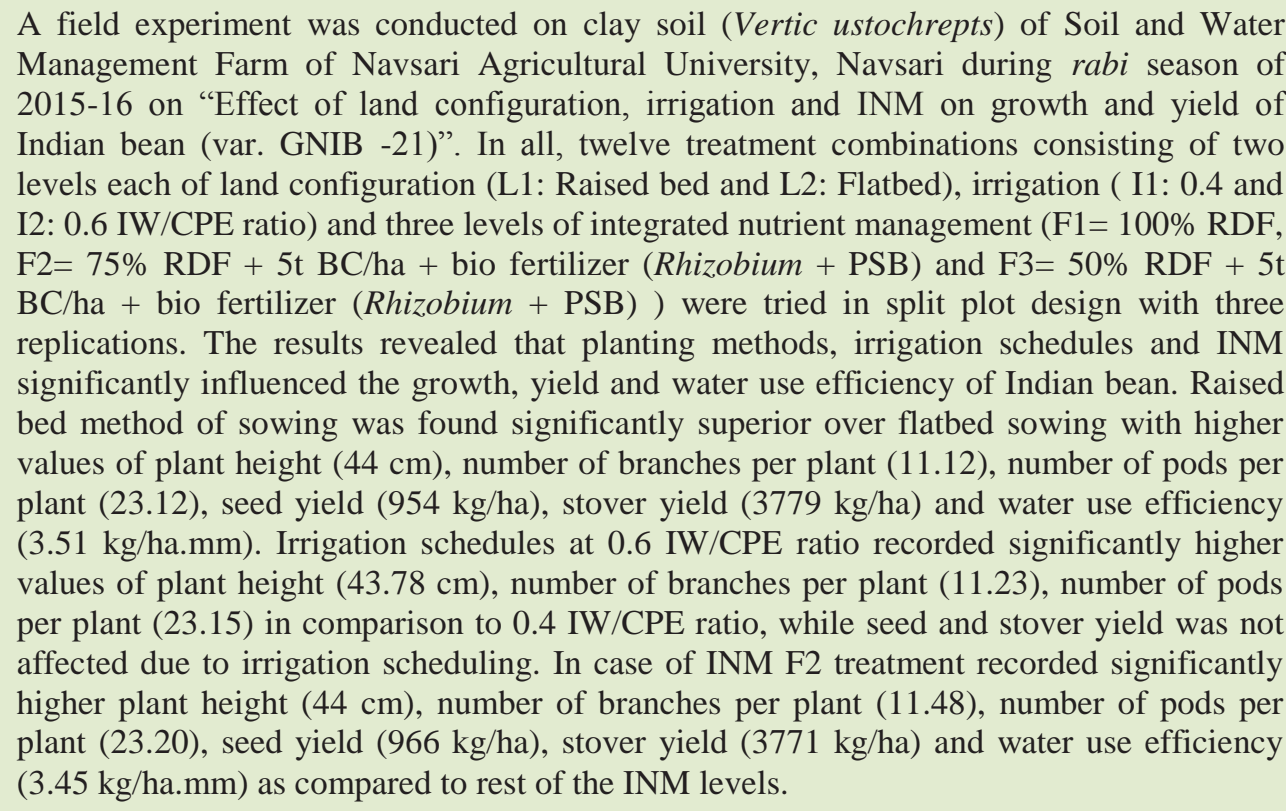 } \\
\hline Keywords & \\
\hline $\begin{array}{l}\text { Land } \\
\text { Configuration, } \\
\text { Irrigation and } \\
\text { INM. }\end{array}$ & \\
\hline Article Info & \\
\hline $\begin{array}{l}\text { Accepted: } \\
23 \text { June } 2017 \\
\text { Available Online: } \\
\text { 10 July } 2017\end{array}$ & \\
\hline & \\
\hline
\end{tabular}

\section{Introduction}

The Indian bean (Dolichos lablab L.) belongs to the family Leguminosae and considered as nutritious vegetables as they contain high amount of vegetable protein, besides carbohydrates and vitamins. The crop has multipurpose use. In south Gujarat, It is mostly grown during rabi season in field vacated by kharif crops like paddy. New variety GNIB -21 found most promising for vegetable purpose due to its short stature plants, early picking and short duration. It became popular among the farmer of South Gujarat due to its suitability as intercrop also, to increase the production of any crops timely and proper management practices has very much importance. Among the various practices, land configuration and irrigation particularly heavy soils has prime important. Beside land configuration, irrigation and nutrients management is also important for 
plant growth and yield and water use efficiency of crop. Due to the popularity of the newly released variety, its demand for quality seed is also increasing. Hence, to decide proper planting method, irrigation schedule and nutrient management for Indian bean grown for seed purpose, the present experiment was planned.

\section{Materials and Methods}

The experiment was conducted on Soil and Water Management Research Unit Farm (SWMRU), Navsari Agricultural University, Navsari during rabi season of 2015-16. The soil of the experimental plot was alkaline in reaction. These soils are locally known as "deep black soil". The colour of dry soil is dark brown and textured clay with medium in organic carbon $(0.52 \%)$, low in available nitrogen $(67.0 \mathrm{~kg} / \mathrm{ha})$, high in phosphorus $(186.1 \mathrm{~kg} / \mathrm{ha})$ and high in available potassium (588.1 kg/ha). Treatment combinations consisting of two levels each of land configuration $\left(\mathrm{L}_{1}\right.$ : Raised bed and $\mathrm{L}_{2}$ : Flatbed), irrigation ( $\mathrm{I}_{1}: 0.4$ and $\mathrm{I}_{2}: 0.6$ IW/CPE ratio) and three levels of integrated nutrient management $\left(\mathrm{F}_{1}=100 \% \mathrm{RDF}, \mathrm{F}_{2}=\right.$ $75 \% \mathrm{RDF}+5 \mathrm{tBC} / \mathrm{ha}+$ bio fertilizer $($ Rhizobium $+\mathrm{PSB})$ and $\mathrm{F}_{3}=50 \% \mathrm{RDF}+5 \mathrm{t}$ $\mathrm{BC} / \mathrm{ha}+$ bio fertilizer (Rhizobium $+\mathrm{PSB})$ ) were tried in split plot design where combination of land configuration and irrigation schedules were allocated to main plots while integrated nutrient management system were assigned to sub plots and replicated thrice. Indian bean cultivar GNIB21 was sown in $6^{\text {th }}$ November with aforesaid treatment and their combinations with $45 \times 10 \mathrm{~cm}\left(\right.$ For $\left.\mathrm{L}_{1}\right)$ and $30 \times 10 \mathrm{~cm}\left(\right.$ For $\left.\mathrm{L}_{2}\right)$ row to row and plant to plant spacing. Crop was fertilized and irrigated as per treatments. For $\mathrm{L}_{1}$ and $\mathrm{L}_{2}$ treatments depth of irrigation was kept $60 \mathrm{~mm}$ and $40 \mathrm{~mm}$, respectively. First common irrigation at $80 \mathrm{~mm}$ depth was given to all the treatments at the time of sowing for uniform germination. Thinning and weeding were done wherever necessary and harvesting was done when crop was fully matured. Observation on growth characters viz., plant height, number of branches per plant 20, 40 and 60 DAS and yield attributes (number of pods per plant and seed per pods) at harvest stage were recorded from previously tagged plants. Seed and stover yield from net plot area was recorded and was subjected to statistical analysis as per method suggested by Panse and Sukhatme (1967).

\section{Results and Discussion}

\section{Growth characters}

Land configuration, irrigation schedules and INM significantly influenced the growth characters (Table 1). The plant height and number of branches per plant recorded at 40 and 60 DAS were significantly higher under raised bed planting method as compared to flatbed sowing. Kumar and Singh (2014) also reported beneficial effect of raised bed planting in French bean for growth attributes. IW/CPE ratio 0.6 produced significantly higher plant height and number of branches per plant at 40 and 60 DAS compared to 0.4 IW/CPE ratio. The beneficial effect of irrigation was not pronounced at 20 DAS, which might be due to less water requirement owing to less foliage, less root development, lower water and nutrient absorption and poor harvesting of solar energy. However, after 20 days, crop responded well to irrigation. There after progressive increase was noticed. Better growth with higher moisture regimes were earlier reported by Singh and Singh (1999) and Kumar and Singh (2014) in French bean. Initially i.e., at 20 DAS plant height and number of branches per plant were not affected significantly due to INM treatments but later on significantly taller plant and higher numbers of branches per plant were observed with $\mathrm{F}_{2}(75 \% \mathrm{RDF}+5 \mathrm{t} \mathrm{BC/ha}+$ bio 
fertilizer (Rhizobium + PSB)) treatment as compared to rest of the INM levels. In most of the cases $\mathrm{F}_{3}$ also had an edge over $\mathrm{F}_{1}$. In $\mathrm{F}_{2}$ and $F_{3}$ treatment bio compost was added, while, in $F_{1}$ only chemical fertilizers were used. So, improvement in growth characters might be due to improvement in physical as well as biological property of soil due to incorporation of bio compost as well as bio fertilizer. Further, bio compost inadvertently added some amount of major and micro nutrient in the soil. Similar results were also reported by Kumar and Singh (2014) in French bean, Mohanty et al., (2015) in green gram and Singh et al., (2015) in mung bean.

\section{Yield and yield at tributes}

Among the yield attributes, only pods per plant was found to be significant due to land configuration treatment (Table 1). Here also, raised bed configuration found superior over flatbed sowing. The better performance of Indian bean crop observed in terms of growth and yield attributes under raised bed $\left(\mathrm{L}_{2}\right)$ sowing also resulted into significantly higher seed and stover yield. An increase in seed and stover yield under raised bed configuration over flatbed were 14.04 and 11.51 percent, respectively. This might be due to cumulative effect exerted from improvement in drainage, soil environment, aeration, root development, $\mathrm{N}$ fixation by nodule bacteria and optimum moisture -air equilibrium throughout the crop growth besides supply of available nutrients to crop. This findings were corroborated the results of Sharma (2003) in black gram, Dhindalwal et al., (2006) in green gram as well as Pandey et al., (2014) in pigeon pea.

The results reported in table 1 , indicated that application of irrigation at higher frequency (IW/CPE ratio 0.6) registered higher number of pods per plant as compared to lower frequency (IW/CPE ratio 0.4). The percent increase in number of pods per plant with $\mathrm{I}_{2}$ treatment over $I_{1}$ treatment was 10.55 . The probable reason for higher number of pods per plant with higher frequency of irrigation $\left(\mathrm{I}_{2}\right)$ over lower frequency of irrigation $\left(\mathrm{I}_{1}\right)$ might be due to adequate moisture available at critical growth stages.

The seed and stover yield of Indian bean was not affected significantly due to irrigation levels. In present study two irrigation ratios i.e., 0.6 and 0.4 were tested. The depth of irrigation for $\mathrm{L}_{1}$ and $\mathrm{L}_{2}$ treatments were 60 and $40 \mathrm{~mm}$, respectively. So, number of irrigation for $\mathrm{L}_{1} \mathrm{I}_{1}, \mathrm{~L}_{1} \mathrm{I}_{2}, \mathrm{~L}_{2} \mathrm{I}_{1}$ and $\mathrm{L}_{2} \mathrm{I}_{2}$ were 3 , 4,4 and 6, respectively. Pulses required less irrigation and critical growth stage for irrigation are branching and pod development stage. Here, minimum number of irrigation was given under treatment $\mathrm{L}_{1}$ was 4 , which met the irrigation requirement of crop. Further, the experimental soil was clayey ( $>60 \%$ clay), that has higher moisture holding capacity that might have adequate supply moisture during the critical growth stage of Indian bean. So, it is very clear that increase in number of irrigation enhanced the vegetative growth but seed and stover yield were not influenced due to increasing number of irrigation. Arya and Sharma (1994) in green gram and Kantwa et al., (2005) in pigeon pea also reported higher yield at 0.4 IW/CPE ratio.

Among the yield at tributes, number of pods per plant was affected significantly due to INM treatments. Similarly, seed as well as stover yield were also influenced significantly due to INM treatments. In all the cases, all three INM treatments differed significantly among themselves. Treatment F2 ranked first followed by F3 and F1. The seed yield recorded under F1, F2 and F3 treatments were 787, 966 and 908, respectively. The corresponding values for stover yield were 3318,3771 and 3596, while that of pods per plant were 20.51, 23.20 and 21.98. 
Table.1 Effect of land configuration, irrigation and INM on growth and yield of Indian bean

\begin{tabular}{|c|c|c|c|c|c|c|c|c|c|c|}
\hline \multirow{2}{*}{ Treatment } & \multicolumn{3}{|c|}{ Plant height $(\mathrm{cm})$} & \multicolumn{3}{|c|}{ Number of branches per plant } & \multirow{2}{*}{$\begin{array}{l}\text { No. of } \\
\text { pods/ } \\
\text { plant }\end{array}$} & \multirow{2}{*}{$\begin{array}{c}\text { No. of } \\
\text { seed/ } \\
\text { pods }\end{array}$} & \multirow{2}{*}{$\begin{array}{c}\text { Seed } \\
\text { yield } \\
\text { (kg/ha) }\end{array}$} & \multirow{2}{*}{$\begin{array}{c}\text { Stover } \\
\text { yield } \\
\text { (kg/ha) }\end{array}$} \\
\hline & 20 DAS & 40 DAS & 60 DAS & 20 DAS & 40 DAS & 60 DAS & & & & \\
\hline \multicolumn{11}{|l|}{ Main plot } \\
\hline \multicolumn{11}{|l|}{ A. Land configuration } \\
\hline $\mathrm{L} 1=$ flat bed & 19.22 & 38.60 & 41.99 & 7.62 & 10.42 & 10.73 & 20.68 & 3.47 & 820 & 3344 \\
\hline L2 = Raised bed & 19.53 & 40.50 & 43.39 & 7.62 & 11.12 & 11.12 & 23.12 & 3.52 & 954 & 3779 \\
\hline S. Em. \pm & 0.45 & 0.47 & 0.31 & 0.19 & 0.10 & 0.11 & 0.21 & 0.05 & 15 & 100 \\
\hline C.D. at $5 \%$ & $\mathrm{NS}$ & 1.62 & 1.09 & $\mathrm{NS}$ & 0.34 & 0.37 & 0.72 & $\mathrm{NS}$ & 51 & 345 \\
\hline \multicolumn{11}{|l|}{ B. Irrigation } \\
\hline $\mathrm{I} 1=0.4 \mathrm{IW} / \mathrm{CPE}$ & 19.49 & 38.65 & 41.59 & 7.66 & 10.57 & 10.62 & 20.64 & 3.44 & 886 & 3591 \\
\hline $\mathrm{I} 2=0.6 \mathrm{IW} / \mathrm{CPE}$ & 19.26 & 40.45 & 43.78 & 7.59 & 10.97 & 11.23 & 23.15 & 3.54 & 888 & 3532 \\
\hline S. Em. \pm & 0.45 & 0.47 & 0.31 & 0.19 & 0.10 & 0.11 & 0.21 & 0.05 & 15 & 100 \\
\hline C.D. at $5 \%$ & $\mathrm{NS}$ & 1.62 & 1.09 & NS & 0.34 & 0.37 & 0.72 & $\mathrm{NS}$ & $\mathrm{NS}$ & $\mathrm{NS}$ \\
\hline CV\% & 9.95 & 5.01 & 3.13 & 10.54 & 3.86 & 4.12 & 4.01 & 5.65 & 7.11 & 11.88 \\
\hline \multicolumn{11}{|l|}{ Sub plot } \\
\hline \multicolumn{11}{|l|}{ Integrated Nutrient Management } \\
\hline $\begin{array}{l}\text { F1 }=100 \% \text { RDF }(20: 40: 00 \text { NPK } \\
\mathrm{kg} / \mathrm{ha})\end{array}$ & 19.03 & 37.88 & 41.61 & 7.55 & 10.08 & 10.37 & 20.51 & 3.41 & 787 & 3318 \\
\hline $\begin{array}{l}\mathrm{F} 2=75 \% \mathrm{RDF}+5 \mathrm{t} \mathrm{BC} / \mathrm{ha}+\text { bio } \\
\text { fertilizer }(\mathrm{PSB}+\text { Rhizobium })\end{array}$ & 19.71 & 41.10 & 43.90 & 7.68 & 11.59 & 11.48 & 23.20 & 3.58 & 966 & 3771 \\
\hline $\begin{array}{l}\mathrm{F} 3=50 \% \mathrm{RDF}+5 \mathrm{t} \mathrm{BC} / \mathrm{ha}+\text { bio } \\
\text { fertilizer }(\mathrm{PSB}+\text { Rhizobium })\end{array}$ & 19.38 & 39.65 & 42.55 & 7.63 & 10.63 & 10.92 & 21.98 & 3.49 & 908 & 3596 \\
\hline S. Em. \pm & 0.28 & 0.48 & 0.51 & 0.12 & 0.15 & 0.10 & 0.18 & 0.08 & 17 & 105 \\
\hline C.D. at $5 \%$ & $\mathrm{NS}$ & 1.44 & 1.54 & NS & 0.45 & 0.30 & 0.55 & $\mathrm{NS}$ & 50 & 315 \\
\hline $\mathrm{CV} \%$ & 5.07 & 4.20 & 4.17 & 5.58 & 4.84 & 3.19 & 2.88 & 7.58 & 6.58 & 10.23 \\
\hline Interaction & $\mathrm{NS}$ & $\mathrm{NS}$ & $\mathrm{NS}$ & $\mathrm{NS}$ & $\mathrm{NS}$ & $\mathrm{NS}$ & $\mathrm{NS}$ & $\mathrm{NS}$ & $\mathrm{L} \times \mathrm{I}$ & $\mathrm{L} \times \mathrm{I}$ \\
\hline
\end{tabular}


Table. 2 Effect of land configuration, irrigation and INM on water use efficiency of Indian bean

\begin{tabular}{|c|c|}
\hline Treatment & $\begin{array}{l}\text { Water use Efficiency } \\
\text { (kg/ha.mm) }\end{array}$ \\
\hline \multicolumn{2}{|l|}{ Main plot } \\
\hline \multicolumn{2}{|l|}{ A. Land configuration } \\
\hline $\mathrm{L}_{1}=$ flat bed & 2.84 \\
\hline $\mathrm{L}_{2}=$ Raised bed & 3.51 \\
\hline S. Em. \pm & 0.05 \\
\hline C.D. at $5 \%$ & 0.19 \\
\hline \multicolumn{2}{|l|}{ B. Irrigation } \\
\hline $\mathrm{I}_{1}=0.4 \mathrm{IW} / \mathrm{CPE}$ & 3.57 \\
\hline $\mathrm{I}_{2}=0.6 \mathrm{IW} / \mathrm{CPE}$ & 2.78 \\
\hline S. Em. \pm & 0.05 \\
\hline C.D. at $5 \%$ & 0.19 \\
\hline $\mathrm{CV} \%$ & 7.36 \\
\hline \multicolumn{2}{|l|}{ Sub plot } \\
\hline \multicolumn{2}{|l|}{ Integrated Nutrient Management } \\
\hline $\mathrm{F}_{1}=100 \% \mathrm{RDF}(20: 40: 00 \mathrm{NPK} \mathrm{kg} / \mathrm{ha})$ & 2.82 \\
\hline $\begin{array}{l}\mathrm{F}_{2}=75 \% \mathrm{RDF}+5 \mathrm{t} \mathrm{BC} / \mathrm{ha}+\text { bio fertilizer }(\mathrm{PSB}+ \\
\text { Rhizobium ) }\end{array}$ & 3.45 \\
\hline $\begin{array}{l}\mathrm{F}_{3}=50 \% \mathrm{RDF}+5 \mathrm{t} \mathrm{BC} / \mathrm{ha}+\text { bio fertilizer }(\mathrm{PSB}+ \\
\text { Rhizobium ) }\end{array}$ & 3.25 \\
\hline S. Em. \pm & 0.06 \\
\hline C.D. at $5 \%$ & 0.19 \\
\hline $\mathrm{CV} \%$ & 7.07 \\
\hline Interaction significant & $\mathrm{L} \times \mathrm{I}$ \\
\hline
\end{tabular}

Fig.1 Seed and stover yield (kg/ha) influenced by interactive effect of land configuration and irrigation
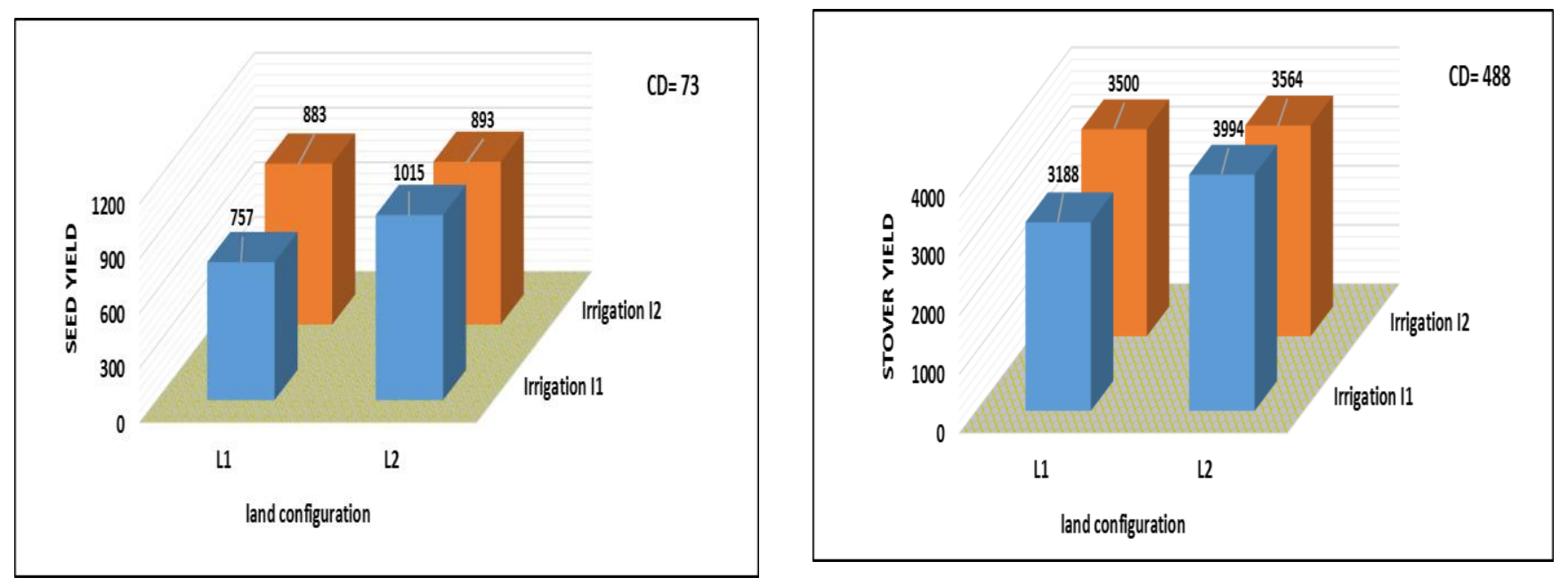
Fig.2 Water use efficiency (kg/ha.mm) influenced by interactive effect of land configuration and irrigation

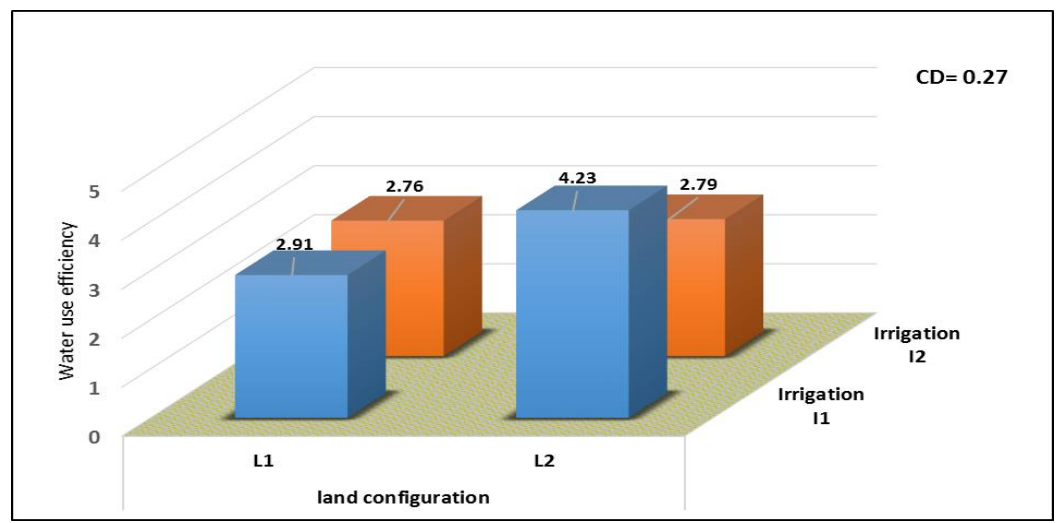

Adequate supply of essential nutrients and micronutrient through chemical fertilizer, bio compost as well as bio fertilizer might have triggered the growth and yield attributes like pods per plant, which ultimately reflected in to seed and stover yield of Indian bean. Kumar and Singh (2014) in French bean, Singh et al., (2015) in mung bean also reported higher yield under INM treatments.

\section{Interaction}

For all the growth characters and yield attributes interact ion effect was absent. But for seed and stover yield it was found to be significant. In both the cases, LxI interact ion was significant. Indian bean grown on raised bed and receiving irrigation of $60 \mathrm{~mm}$ depth at $0.4 \mathrm{IW} / \mathrm{CPE}$ ratio resulted into significantly higher seed yield $(1015 \mathrm{~kg} / \mathrm{ha})$ as well as stover yield (3994 kg/ha) (Fig. 1) as compared to rest of the treatments. Here, the crop was grown on raised bed and total 4 irrigations of $40 \mathrm{~mm}$ depth were given at an interval of 19 days. So, crop might have got good drainage and aeration as well as light irrigation at all the critical growth stages. This might be the probable reason for higher yield under this treatment.

\section{Water use efficiency (WUE)}

WUE of Indian bean was markedly influenced by main effect of land configuration, irrigation and INM (Table 2) as well as interactive effect of land configuration and irrigation (LxI) (Fig. 2). Raised bed system with $3.51 \mathrm{~kg} / \mathrm{ha} \mathrm{mm}$ of WUE out performed flatbed sowing (2.84 $\mathrm{kg} / \mathrm{ha} . \mathrm{mm})$. In case of irrigation treatment, $\mathrm{I}_{1}$ $(3.57 \mathrm{~kg} / \mathrm{ha} . \mathrm{mm})$ had an edge over $\mathrm{I}_{2}(2.78$ $\mathrm{kg} / \mathrm{ha} . \mathrm{mm}$ ). The water given in treatment $I_{1}$ and $\mathrm{I}_{2}$ was 200 and 260 to 280 ha.mm, respectively, while the seed yield was not significant, that gave the higher WUE in treatment $\mathrm{I}_{1}$. So far as INM treatment is concerned, treatment $F_{2}$ out yielded rest of the two treatments by recording significantly higher WUE of $3.45 \mathrm{~kg} / \mathrm{ha} . \mathrm{mm}$. In case of $\mathrm{L} \times \mathrm{I}$ interaction, $\mathrm{L}_{2} \mathrm{I}_{1}$ ranked first with WUE of $4.23 \mathrm{~kg} / \mathrm{ha} . \mathrm{mm}$. Here, least amount of water given at higher frequency. That might stimulate yield and ultimately WUE. Higher WUE with lower IW/CPE ratios were also been reported by Dhonde et al., (1985) in chickpea. Similarly, Gupta and Sharma (1994) from Madhya Pradesh in soybean, Shelke et al., (1998) from Parbhani (Maharashtra) in pigeon pea, Pramanik et al., (2009) from Uttar Pradesh in chickpea, also reported higher water use efficiency with land configuration treatments.

In conclusion, for obtaining higher seed yield of Indian bean after kharif paddy under South Gujarat conditions, the crop should be grown by adopting raised bed method of sowing and irrigated at $0.4 \mathrm{IW} / \mathrm{CPE}$ ratio, which required 4 irrigations (each of $40 \mathrm{~mm}$ depth). First irrigation at the time of sowing and remaining three at an interval of 19 days. Further, for achieving higher seed yield of Indian bean 
along with maintenance of soil fertility, crop should be fertilized with $75 \% \mathrm{RDF}+5 \mathrm{t} \mathrm{BC} / \mathrm{ha}$ + bio fertilizer (Rhizobium + PSB).

\section{References}

Arya, R.L. and Sharma, J.P. 1996. Efficacy of irrigation schedules and antitranspirant/growth regulators on yield, nutrient uptake and economics of summer mungbean. Indian J. pulses Res., 9(1): 1824.

Dhindwal, A.S., Hooda, I.S., Malik, R.K. and Kumar, S. 2006. Water productivity of furrow-irrigated rainy season pulses planted on raised beds. Indian J. Agron., 51(1): 49-53.

Dhonde, P.W., Shindhe, S.H., Patil, B.B. and Pawar, A.D. 1985. Irrigation scheduling to chickpea. J. Maharashtra Univ., 11(2): 164-166.

Gupta, R.K. and Sharma, R.A. 1994. Influence of different land configurations on in situ conservation of rain water, soil and nutrients. Crop Res., 8(2): 276-282.

Kantwa, S.R., Alawat, I.P.S. and Gangaiah, B. 2005. Effect of land configuration, postmonsoon irrigation and phosphorus on performance of sole and intercropped pigeonpea (Cajanus cajan L.). Indian J. Agron., 50(4): 278-280.

Kumar, Binod and Singh, G.R. 2014. Response of Land configuration, IW/CPE ratio and integrated nutrient supply system on growth function, yield and water use efficiency of French bean (Phaseolus vulgaris L. PDR-14). Int. J. Agri. Environ. Biotechnol., 7(4): 825-831.

Mohanty, T.R., Roul, P.K., Maity, S.K. and Nayak, A. 2015. Productivity and profitability of greengram (Vigna radiate
L.) as influenced by rice crop establishment and nutrient management practices in rice-greengram cropping system. J. Crop and Weed, 11(1): 92-97.

Pandey, I.B., Tiwari, S., Pandey, R. K. and Rakesh Kumar. 2014. Effect of bed configuration, fertilizer levels and placement method on the productivity of long duration pigeon pea under rainfed condition. J. Food Legume, 27(3): 206209.

Panse, V.G. and Sukhatme, P.V. 1967. Statistical methods for agricultural workers. ICAR, New Delhi. Pp. 187-197.

Pramanik, S.C., Singe, N.B. and Singh, K.K. 2009. Yield, economics and water use efficiency of chickpea (Cicer arientinum L.) under various irrigation regimes on raised bed planting system. Indian $J$. Agron., 54(3): 315-318.

Sharma, P.K. 2003. Raised-sunken bed system for increasing productivity of rice-based cropping system in high rainfall areas of Himachal Pradesh. J. Indian Society of Soil Sci., 51(1): 10-16.

Shelke, D.K., Sondge, V.D., Oza, S.R. 1998. Response of pigeon pea to irrigation schedules and methods under rainfed situation. J. Maharashtra Agric. Univ., 23(3): 316.

Singh, G. and Singh, T.P. 1999. Effect of moisture regime and fertility levels on growth, yield and water use of French bean (Phaseolus vulgaris L.). Indian J. Agron., 44(2): 389-391.

Singh, S.P., Ram Bhasose, A. and Suresh Kumar. 2015. Response of summer mungbean to phosphorus and biofertilizers in eastern Uttarpradesh, Annals of Plant and Soil Res., 17(1): 104-105.

\section{How to cite this article:}

Sodavadiya, H.B., V.R. Naik and Chaudhari, S.D. 2017. Effect of Land Configuration, Irrigation and INM on Growth, Yield and Water Use Efficiency of Indian Bean (var. GNIB-21). Int.J.Curr.Microbiol.App.Sci. 6(7): 2624-2630. doi: https://doi.org/10.20546/ijcmas.2017.607.310 